\title{
ACUTE EFFECT OF SPEED TEST ON THE SKIN TEMPERATURE OF ELITE SOCCER PLAYERS
}

FUTEBOL DEELITE

\author{
EFECTO AGUDO DEL TEST DE VELOCIDAD SOBRE LA TEMPERATURA DE LA PIEL DE JUGADORAS DE \\ FÚTBOL DEÉLITE
}

\section{Andressa Mella Pinheiro' (ID (Physical Education Professional) Angélica Tamara Tuono ${ }^{1}$ (ID (Physical Education Professional) Nathália Arnosti Vieira' (ID (Physical Education Professional) Tiago Marques de Rezende ${ }^{1}$ (ID (Physical Education Professional) Sérgio Henrique Borin ${ }^{2}$ (ID (Physical Therapist) \\ Charlini Simoni Hartz ${ }^{2}$ (D) (Physical Therapist) Carlos Roberto Padovani ${ }^{3}$ (ID (Statistician) \\ Fernando Carmelo Torres ${ }^{4,5}$ (ID (Physician)}

João Paulo Borin ${ }^{1}$ (ID

(Physical Education Professional)

1. Universidade Estadual de Campinas (UNICAMP), Faculdade de Educação Física, Campinas, SP, Brazil.

2. Universidade Metodista de Piracicaba (UNIMEP), Graduate Program in Human Movement Sciences, Piracicaba, SP, Brazil. 3. Universidade Estadual de São Paulo (UNESP), Department of Biostatistics, Botucatu, SP, Brazil. 4. Universidade Federal de São Paulo (UNIFESP), São Paulo, SP, Brazil.

5. Universidade Paulista (UNIP), Center for Exercise Physiology and Training Studies (CEFIT), São Paulo, SP, Brazil.

\section{Correspondence:}

Andressa Mella Pinheiro. Rua Laura Siqueira Santos, 110, Terras de Santa Bárbara, Santa Bárbara d'Oeste, São Paulo, SP, Brasil. andressamella@gmail.com

\begin{abstract}
Introduction: Infrared thermography has been used in several areas, mainly in sports training, and specifically in soccer. Objectives: The objectives of the study were to verify the acute effect of a displacement speed test on the skin temperature of elite female soccer players, to observe pre- and post-test thermal asymmetries, and to compare responses in the anterior and posterior regions of lower limbs. Methods: Cross-sectional study that evaluated 17 soccer players of the 2018 Brazilian Championship. They were submitted to thermography before and 10 minutes after performing the displacement speed test. Thermographic images were collected using a FLIR ${ }^{\circledast}$ model 8 thermal imager and changes in skin temperature in the anterior and posterior regions of the lower limbs were analyzed, according to the areas of interest. Descriptive statistics were performed and mean and standard deviation of the temperatures of the areas of interest were analyzed. The normality of the data was verified, and then the Student's $t$ test for normal paired and independent samples and the Mann-Whitney test for non-normal samples were conducted, with $p<0.05$ being adopted for significance level. Results: It was possible to observe that after the test there was an increase in skin temperature in all the regions analyzed, both on the dominant and non-dominant sides $(p<0.05)$. Regarding the analysis of the anterior region, it was possible to observe a higher temperature $(p<0.05)$ in the region of the tibial muscles than in the region of the quadriceps muscles. Conclusion: It is concluded that thermography helps to understand the thermal responses of lower limbs after applying the displacement speed test. The study shows that thermographic evaluation can guide the organization of the training session when motor tests have previously been applied, and in the detection of abnormal overloads, helping to prevent injuries. Level of evidence IV; Therapeutic studies - Investigation of treatment results.
\end{abstract}

Keywords: Thermography; Women; Control; Exercise; Soccer.

\section{RESUMO}

Introdução: A termografia infravermelha tem sido empregada em diversas áreas, principalmente no treinamento esportivo e especificamente no futebol. Objetivos: Os objetivos do estudo foram verificar o efeito agudo da aplicação de um teste de velocidade de deslocamento sobre a temperatura da pele de atletas de futebol feminino de elite, as assimetrias térmicas pré e pós-teste e comparar respostas nas regiões anterior e posterior de membros inferiores. Métodos: Estudo de caráter transversal, que avaliou 17 jogadoras de futebol do Campeonato Brasileiro em 2018. Elas foram submetidas à termografia antese 10 minutos depois da realização do teste de velocidade de deslocamento. Foram coletadas imagens termográficas por meio de um termovisor FLIR', modelo E8, e analisadas as alterações da temperatura da pele, na região anterior e posterior dos membros inferiores, de acordo com as áreas de interesse. Foi realizada a estatística descritiva e para análise, foram usados média e desvio padrão da temperatura das áreas pretendidas. Verificou-se normalidade dos dados e, em seguida, o teste $t$ de Student para amostras normais pareadas e independentes e o teste de Mann-Whitney, para amostras não normais, adotando-se $p<0,05$ para nivel de significância. Resultados: Foi possível observar que depois do teste houve aumento da temperatura da pele em todas as regiöes analisadas, tanto no lado dominante quanto no não dominante $(p<0,05)$. Com relação à análise da região anterior, foi possível observar maior temperatura $(p<0,05)$ na região dos músculos tibiais quando comparados com os músculos da região do quadriceps. Conclusão: Conclui-se que a termografia auxilia o entendimento das respostas térmicas de membros inferiores depois da aplicação do teste de velocidade de deslocamento. O estudo demonstra que a avaliação termográfica pode orientar a organização da sessão de treinamento quando há aplicação prévia de testes motores e na detecção de sobrecargas anormais, auxiliando na prevenção de lesões. Nível de evidência IV; Estudos terapêuticos - Investigação dos resultados do tratamento.

Descritores: Termografia; Mulheres; Controle; Treinamento físico; Futebol.

\section{RESUMEN}

Introducción: La termografía infrarroja ha sido empleada en diversas áreas, principalmente en el entrenamiento deportivo y especificamente en el fútbol. Objetivos: Los objetivos del estudio fueron verificar el efecto agudo de la 
aplicación de un test de velocidad de desplazamiento sobre la temperatura de la piel de atletas de fútbol femenino de élite, las asimetrías térmicas prey post test y comparar respuestas en las regiones anterior y posterior de miembros inferiores. Métodos: Estudio de carácter transversal, que evaluó a 17 jugadoras de fútbol del Campeonato Brasileño en 2018. Ellas fueron sometidas a termografía antes y 10 minutos después de la realización del test de velocidad de desplazamiento. Fueron colectadas imágenes termográficas por medio de un termovisor FLIR - E8, modelo E8, y analizadas las alteraciones de la temperatura de la piel, en la región anteriory posterior de los miembros inferiores, de acuerdo con las áreas de interés. Fue realizada la estadística descriptiva y para el análisis, fueron usados promedio y desviación estándar de la temperatura de las áreas pretendidas. Severificó normalidad de los datos y, a continuación, el test $t$ de Student para muestras normales pareadas e independientes, y el test de Mann-Whitney, para muestras no normales, adoptándose $p<0,05$ para nivel de significancia. Resultados: Fue posible observar que después del test hubo aumento de la temperatura de la piel en todas las regiones analizadas, tanto en el lado dominante como en el no dominante $(p<0,05)$. Con relación al análisis de la región anterior, fue posible observar mayor temperatura $(p<0,05)$ en la región de los músculos tibiales cuando comparados con los músculos de la región del cuádriceps. Conclusión: Se concluye que la termografía ayuda en el entendimiento de las respuestas térmicas de miembros inferiores, después de la aplicación del test de velocidad de desplazamiento. El estudio demuestra que la evaluación termográfica puede orientar la organización de la sesión de entrenamiento cuando hay aplicación previa de tests motores y en la detección de sobrecargas anormales, ayudando en la prevención de lesiones. Nivel de evidencia IV;

Estudios terapéuticos - Investigación de los resultados del tratamiento.

Descriptores: Termografía; Mujeres; Control; Ejercicio Físico; Fútbol.

\section{INTRODUCTION}

In recent years, women's soccer has seen an increase in the number of athletes at different levels and championships, mainly after the new licensing rules of the South American Football Confederation, turning it into a noteworthy sports category within the high-performance sports.

Regarding its characterization, soccer has been considered an intermittent modality as its official matches require numerous motor actions, such as accelerations/decelerations, jumps and changes of direction at different intensities, and the competitive performance of players can be influenced by the interaction of different motor skills ${ }^{1,2}$.

Over the years and with the sport's evolution, soccer has undergone changes in its dynamics, and, consequently, games have become faster ${ }^{3}$, causing displacement speed to become one of the determining skills in competitive performance. In this sense, the increase in size of the championships and in the number of games played has contributed to these changes in the competitive environment, especially in elite soccer, which means that evaluations of this motor skill are carried out regularly in order to serve as a parameter of training control.

Particularly in relation to training control parameters, different indicators have contributed to monitor the athlete's progress, and one of the resources most frequently employed to assess speed is the 30-meter displacement test proposed by Little and Willians ${ }^{4}$. In fact, it seems to be a daily practice in sports environments to apply motor tests in order to diagnose and monitor the evolution of the athlete's performance throughout the season, but a problem to be pointed out is how much these tests influence or if they can be used before the training session.

In this regard, different tools have emerged to assist in the control and monitoring of training, such as infrared thermography, which is a method of capturing images that detects changes in skin temperature ${ }^{5}$. Notably, infrared thermography has shown impressive results in different areas of knowledge, mainly in the health sciences. It can be used as an auxiliary tool in the diagnosis of diseases such as cancer, musculoskeletal injuries and even in the evaluation of clinical and aesthetic procedures, as it is a non-invasive, radiation-free and highly accurate technique $e^{6,7,8}$.

In the scope of sports training, specifically in the control and monitoring of training, some studies have contributed to the detection of overload and skeletal muscle fatigue in elite athletes, and also to the control and prevention of injuries arising from sports practice ${ }^{9,10}$, however, there is no information regarding the responses on skin temperature after application of motor tests, mainly in elite female soccer athletes. Therefore, the objectives of this study are: a) to verify the acute effect of the application of a displacement speed test on skin temperature of elite female soccer athletes; b) to identify possible thermal asymmetries before and after applying the test; $c$ ) to compare skin temperature response of the anterior and posterior regions of the lower limbs of female soccer players.

\section{MATERIALS AND METHODS}

\section{Research design and participants}

This study is observational and involves elite female soccer players. An intentional sample was selected, and included 17 female soccer athletes, aged $21.9 \pm 4.7$ years old on average, with a mean body mass of $59.6 \pm$ $8.0 \mathrm{~kg}$, a mean fat percentage of $16.6 \pm 3.7$, and a mean height of 1.64 $\pm 4.9 \mathrm{~cm}$. The following inclusion criteria were observed: not having any orthopedic limitations, not using any stimulating substance and being present in the data collection.

The study was carried out in the competitive period of the adult category of the Brazilian Championship in 2018, with an average of two games per week. The athletes trained six times a week, with an average duration of 90 minutes, beginning the work with stretching exercises and general muscle warm-up, followed by a training session programmed by the technical committee.

All volunteers signed an informed consent form. The project was approved by the Research Ethics Committee under CAEE protocol number 00348818.1.0000.5404

\section{Data collection procedure}

The athletes were submitted to the thermographic evaluation protocol before and after the displacement speed test application. The infrared images were collected using a FLIR ${ }^{\circledR}$ thermal imager, E8 model. This device has an integrated $320 \times 240$ pixel resolution, making it possible to measure temperatures between $-20^{\circ} \mathrm{C}$ and $250^{\circ} \mathrm{C}$, with thermal sensitivity $<0.06^{\circ} \mathrm{C}$.

Before the data collection the athletes were instructed not to consume caffeine or alcohol, not to use any type of product on their skin, 
not to take any medication, and not to perform physical exercises in the 24 hours preceding data collection. They were also instructed not to apply pressure on, rub or scratch their skin at any time until the entire collection process was completed ${ }^{11}$.

For the initial collection, the thermographic camera was stabilized by placing it in the evaluation room and turning it on 20 minutes before the procedure. The athletes stayed 20 minutes in a previously prepared room, conditioned at $22^{\circ} \mathrm{C}$ to obtain thermal balance. They all remained in an anatomical position in front of the evaluator, on a carpet, at a distance of two meters from the thermal imager. The thermographic images were taken at the initial moment (pre) and repeated 20 minutes after the speed test application (post) ${ }^{12}$. Two images were captured, one in the anterior and one in the posterior plane. The analysis of the thermograms was performed using the Flir Tools ${ }^{\oplus}$ software, considering the areas for the following regions of interest (ROIs): quadriceps, anterior tibialis, hamstrings and calf, as shown in Figure 1.

Displacement speed was assessed using the 30-meter speed test, according to the protocol described by Little and Willians ${ }^{4}$, in which athletes should cover the total distance of $30 \mathrm{~m}$ as quickly as possible. All athletes were submitted to a five-minute warm-up protocol, consisting of light running and short sprints. Four pairs of photocells (Speed Test Fit ${ }^{\circledast}$ - Cefise) were positioned one meter high, the first on the starting line, the second on the 10-meter mark, the third on the 20-meter mark, and, finally, the fourth on the final 30-meter mark. Each athlete made two attempts, with a three-minute interval between each one, and the best result obtained was the one used for analysis.

\section{Statistical analysis}

The data were presented using descriptive statistics (mean \pm standard deviation), and, after verifying data normality through the Shapiro-Wilk test, they were submitted to the Student's T test for normal paired and independent samples. When data normality wasn't detected the Mann-Whitney test for non-normal samples was used. Significance level of $p<0.05$ was adopted for the analyses.

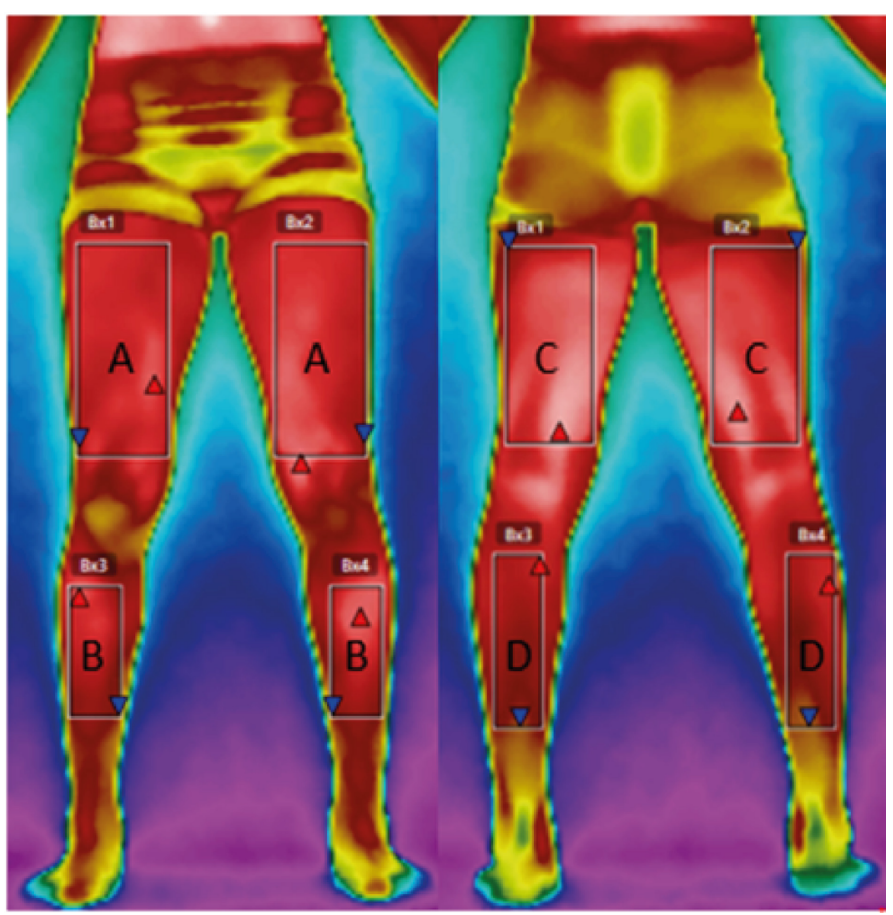

Figure 1. Regions of interest (ROls) used for the analysis ( $\mathrm{A}$ - quadriceps; $\mathrm{B}$ - anterior tibialis; C - hamstrings; D - calf)

\section{RESULTS}

From the data obtained, the results will be presented according to the values of the skin temperature of the ROls relative to the moment of evaluation (Table 1), thermal asymmetry (Table 2), and temperature of the anterior and posterior regions (Table 3 ).

Table 1 illustrates the results of the comparison of skin temperature before and after the speed test, making it possible to observe a significant increase in the ROls temperature after the test, both in the dominant and non-dominant limbs. $(p<0.05)$.

Table 2 refers to the analysis of the temperature difference between the dominant and non-dominant limbs, and it was possible to note that there was no thermal asymmetry in any of the analyzed regions, both before and after the speed test's application.

Table 3 shows the temperature of the analyzed regions (anterior and posterior) of each body segment, according to dominance. The data demonstrate that there was a significant skin temperature difference $(p<0.05)$ in the leg, as the tibial region showed higher temperatures compared to the calf, both before and after the test, on both sides.

\section{DISCUSSION}

Based on the data obtained, the present discussion will be divided into three moments. The first moment highlights the effect of the displacement speed test on the skin temperature of the lower limbs. In the second moment, the thermal asymmetry of the lower limbs will be addressed, and, lastly, the regions that most experienced changes in skin temperature will be presented.

Regarding the speed test effect on skin temperature, the data point to an increase in all analyzed regions following its application. Other studies have sought to identify skin temperature changes while and after performing various exercises, such as squatting, running, cycling, rowing and swimming ${ }^{13-19}$ but the effects of specific tests on this parameter have not been identified ${ }^{20-22}$.

After the 30-meter speed test application, it was noted that there was an increase in the temperature of all the regions analyzed, both in the dominant and non-dominant limbs, differing from the results of the study by Korman et al. ${ }^{14}$, who found a decrease in skin temperature after subjecting sprinters of the Polish athletics team to a speed resistance training session, with distances ranging from $60 \mathrm{~m}$ to $120 \mathrm{~m}$. The data may have diverged due to the analysis technique adopted, as in the study by Korman et al. ${ }^{14}$, the mean skin temperature of the lower limbs as a whole was considered, whereas in this study the analysis was performed using only the quadriceps and the hamstrings.

In a test performed on a treadmill, Merla et al. ${ }^{12}$ verified the subjects skin temperature response while running, with a gradual increase in intensity. It was found that, at the end of the test, there was a skin temperature increase of approximately $0.2^{\circ} \mathrm{C}$ in the region of the thighs,

Table 1. Mean temperature of the analyzed regions and standard deviation, according to the moment of evaluation.

\begin{tabular}{c|c|c|c|c}
\hline \multirow{2}{*}{ Limb } & \multirow{2}{*}{ ROIs } & \multicolumn{2}{|c|}{ Moments of Evaluation } & \\
\cline { 3 - 5 } & & Pre-test & Post-test & $\begin{array}{c}\text { Temperature } \\
\text { difference }\left({ }^{\circ} \mathbf{C}\right)\end{array}$ \\
\hline \multirow{4}{*}{ Dominant } & Quadriceps & $28.6 \pm 0.6$ & $29.8 \pm 0.6^{*}$ & 0.2 \\
\cline { 2 - 5 } & Hamstrings & $28.6 \pm 0.4$ & $29.8 \pm 0.7^{*}$ & 1.2 \\
\cline { 2 - 5 } & Anterior tibialis & $28.6 \pm 0.2$ & $30.0 \pm 0.4^{*}$ & 1.4 \\
\cline { 2 - 5 } & Calf & $28.3 \pm 0.7$ & $29.2 \pm 0.7^{*}$ & 0.9 \\
\hline \multirow{3}{*}{ Non-dominant } & Quadriceps & $28.5 \pm 0.6$ & $29.8 \pm 0.6^{*}$ & 1.3 \\
\cline { 2 - 5 } & Hamstrings & $28.7 \pm 0.4$ & $30.0 \pm 0.8^{*}$ & 1.3 \\
\cline { 2 - 5 } & Anterior tibialis & $28.8 \pm 0.3$ & $29.9 \pm 0.4^{*}$ & 0.9 \\
\cline { 2 - 5 } & Calf & $28.6 \pm 0.5$ & $29.5 \pm 0.6^{*}$ & 0.9 \\
\hline
\end{tabular}

${ }^{*} p<0.05$. 
Table 2. Mean temperature of the analyzed regions and standard deviation, according to dominance.

\begin{tabular}{c|c|c|c|c|c|c|c|c}
\hline \multirow{2}{*}{ Moments } & \multicolumn{9}{|c|}{ Analyzed regions } & \multicolumn{3}{|c}{ Anterior tibialis } & \multicolumn{2}{c}{ Calf } \\
\cline { 2 - 10 } & Dominant & Non-dominant & Dominant & Non-dominant & Dominant & Non-dominant & Dominant & Non-dominant \\
\hline \multirow{2}{*}{ Pre $\left({ }^{\circ} \mathrm{C}\right)$} & $28.6 \pm 0.3$ & $28.6 \pm 0.3$ & $28.6 \pm 0.1$ & $28.7 \pm 0.1$ & $28.6 \pm 0.2$ & $28.8 \pm 0.3$ & $28.1 \pm 0.2$ & $28.1 \pm 0.2$ \\
\hline Post $\left({ }^{\circ} \mathrm{C}\right)$ & $29.8 \pm 0.4$ & $29.8 \pm 0.5$ & $29.8 \pm 0.6$ & $30.0 \pm 0.7$ & $30.0+0.4$ & $29.9 \pm 0.4$ & $29.2 \pm 0.6$ & $29.5 \pm 0.4$ \\
\hline
\end{tabular}

Table 3. Mean temperature of the anterior and posterior regions of the lower limbs and standard deviation, according to the moment of evaluation.

\begin{tabular}{c|c|c|c|c}
\hline & \multicolumn{4}{|c}{ ROls } \\
\hline & \multicolumn{2}{|c|}{ Dominant side } & \multicolumn{2}{c}{ Non-dominant side } \\
\hline Moments & Quadriceps & Hamstrings & Quadriceps & Hamstrings \\
\hline Pre & $28.6 \pm 0.3$ & $28.6 \pm 0.1$ & $28.6 \pm 0.3$ & $28.7 \pm 0.1$ \\
\hline Post & $29.8 \pm 0.4$ & $29.8 \pm 0.6$ & $29.8 \pm 0.5$ & $30.0 \pm 0.7$ \\
\hline & Anterior tibialis & Calf & Anterior tibialis & Calf \\
\hline Pre & $28.6 \pm 0.2^{*}$ & $28.1 \pm 0.2$ & $28.8 \pm 0.3^{*}$ & $28.1 \pm 0.2$ \\
\hline Post & $30.0+0.4^{*}$ & $29.2 \pm 0.6$ & $29.9 \pm 0.4^{*}$ & $29.5 \pm 0.4$ \\
\hline${ }^{*} p<0.05$. & & &
\end{tabular}

results that are close to those of this study (Table 1). Fernandes et al. ${ }^{15}$ found an increase in the temperature of the anterior and posterior thigh and of the calf after a 60 -minute session of aerobic exercise at $60 \%$ of the $\mathrm{VO}_{2}$ max, results that are analogous to those found in the present study. Santa Cruz et al. ${ }^{22}$ evaluated the skin temperature of handball players after an official match and found temperature variations in the region of the quadriceps $\left(0.2^{\circ} \mathrm{C}\right.$ on the right side and $0.1^{\circ} \mathrm{C}$ on the left side) and hamstrings $\left(0.4^{\circ} \mathrm{C}\right.$ on the right side and $0.2^{\circ} \mathrm{C}$ on the left side), but without statistical difference. This behavior can be explained by the orientation of blood flow towards the most active regions ${ }^{23}$, especially when it comes to maximum protocols, as was the case of the $30 \mathrm{~m}$ test $^{24}$. This information is of extreme importance in the planning of the training session that will follow the test application, since it offers the possibility to identify which regions had a higher demand and to plan the session avoiding excessive overload of those regions.

In soccer, specifically, studies have sought to verify thermal asymmetries in order to identify and prevent injuries ${ }^{25}$. Regarding the results of thermal asymmetry, it was possible to note that there was no asymmetry in any of the regions analyzed, i.e., there was no contralateral difference greater than $0.3^{\circ} \mathrm{C}$, both before and after the test, indicating that there was no additional overload in none of the body hemispheres, since the differences found $\left(0.1^{\circ} \mathrm{C}\right.$ to $\left.0.3^{\circ} \mathrm{C}\right)$ agree with the literature, which classifies asymmetry values $<0.5^{\circ} \mathrm{C}$ as normal ${ }^{26}$. A study by Stroppa et al. ${ }^{27}$ also applied thermography to professional soccer players, seeking to verify thermal asymmetries only in the knee region, and found no statistical difference between limbs, both in the anterior and posterior regions. This study is in line with our findings, which also found no statistical difference in the moments before and after the test.

Although this study did not find thermal asymmetry between the dominant and non-dominant limbs, it draws attention to the higher skin temperature in the tibial region on both sides compared to the quadriceps, both before and after the test. A study by Fernandes et al. ${ }^{28}$ verified the effect of a soccer match on the skin temperature of the lower limbs, and observed that 24 hours after the match, there was an average increase of $2.2^{\circ} \mathrm{C}$, together with a $561 \%$ increase in creatine kinase (CK), in comparison to the pre-match values, which indicates micro muscle injuries. These results show that there may be a relationship between skin temperature increase in the tibial region and the activity of enzymes related to injury and/or inflammation, suggesting greater mechanical stress on this region that is responsible for stabilizing the ankle joint, especially when performing eccentric actions, which are prevalent in soccer and sprints, as is the case of the displacement speed test ${ }^{29}$.

This temperature increase in the tibial region may also be related to biomechanical factors (joint mobility, postural deviations, level of flexibility, among others). In this sense, Rodriguez-Sanz et al. ${ }^{30}$ assessed the ankle flexibility of soccer players, and then subjected the athletes to an $8 \mathrm{~km} / \mathrm{h}$ run on a treadmill for 15 minutes. Before and after the running protocol thermographic images were collected and it was found that the flexibility level of the ankle joint can influence temperature increase in muscles overloaded by mechanical changes in the joint. That being so, infrared thermography seems to be an important tool to monitor both training sessions and test sessions for evaluation and control, since the increase in skin temperature may indicate additional, and even abnormal, overloads that contribute to the occurrence of injuries.

\section{CONCLUSION}

It is concluded that, after the application of the 30-meter speed test there was an increase in the temperature of all analyzed regions, which may have been caused by the orientation of blood flow towards the areas with greatest activation. After applying the test, there was no thermal asymmetry between the dominant and non-dominant limbs, but higher skin temperature increase was found in the tibial region, on both sides, compared to the quadriceps.

\section{Practical applications}

The data presented here point to different practical applications that different members of the technical committee can use. It enables the technical team to be more attentive in the organization of the training session when there is application of speed test at the beginning of the session, mainly in relation to the region of the anterior tibial muscle. In the monitoring and control of training, thermography proved to be a tool that can help detect minimal changes in skin temperature, which may reflect a muscular overload. In addition, from the identification of thermal asymmetries, the technical committee can define which recovery procedures can be employed to minimize muscle overload and assist in injury prevention.

\section{ACKNOWLEDGMENT}

The authors thank Espaço da Escrita - Pró-Reitoria de Pesquisa UNICAMP - for the language services provided.

All authors declare no potential conflict of interest related to this article

AUTHORS' CONTRIBUTIONS: EEach author made significant individual contributions to this manuscript. AMP: Substantial contribution to the concept and design of the work, data acquisition, writing. ATT: Data acquisition and revision of the article. NAV and TMR: Data acquisition and substantial contribution to the concept and design of the work. SHB and CSH: Data acquisition and analysis. CRP: Data analysis and interpretation and critical review of the intellectual content. FCT:Writing and revision of the article. JPB: Substantial contribution to the concept and design of the work, critical review of the intellectual content and approval of the final version of the text. 


\section{REFERÊNCIAS}

1. Stølen T, Chamari K, Castagna C, Wisløff U. Physiology of soccer: An update. Sport Med. 2005;35(6):501-36.

2. Bezerra JA, Oliveira Farias N, Melo VAS, Silva PMR, Castro CMA, Martins SBF, et al. Respostas de indicadores fisiológicos a um jogo de futebol. Rev Bras Med Esporte. 2016;22(3):200-5.

3. Ellwanger W, Crescente LAB, Garlipp DC, Siqueira OD. Análise da distância percorrida por futebolistas na Copa do Mundo de 2014. Rev Bras Futsal e Futeb. 2017;9(33):165-9.

4. Little T, Williams AG. Specificity of Acceleration, Maximum Speed, and Agility in Professional Soccer Players. J Strength Cond Res. 2005;19(1):76-8.

5. Côrte ACR, Hernandez AJ. Termografia médica infravermelha aplicada à medicina do esporte. Rev Bras Med Do Esporte. 2016;22(4):315-19.

6. Shimatani A, Hoshi M, Oebisu N, Iwai T, Takada N, Nakamura H. Clinical significance of thermal detection of soft-tissue tumors. Int J Clin Oncol. 2020;25(7):1418-24.

7. Singh $D$, Singh AK. Role of image thermography in early breast cancer detection- Past, present and future. Comput Methods Programs Biomed. 2020;183:105074.

8. Sanchis-Sánchez E, Vergara-Hernández C, Cibrián RM, Salvador R, Sanchis E, Codoñer-Franch P. Infrared thermal imaging in the diagnosis of musculoskeletal injuries: A systematic review and meta-analysis. Am J Roentgenol. 2014;203(4):875-82.

9. Neves EB, Reis VM. Fundamentos da Termografia para o Acompanhamento do Treinamento Desportivo. Rev UNIANDRADE. 2014;15(2):79-86.

10. Hadžić V, Širok B, Malneršič A, Čoh M. Can infrared thermography be used to monitor fatigue during exercise? A case study. J Sport Heal Sci. 2019;8(1):89-92.

11. Pinto TWS, Guimarães ASP, Barreto TC, Santa Cruz RA. Alterações termográficas na musculatura abdominal após exercício estático e dinâmico em jovens ativas. Rev Perspect Cienc e Saúde. 2018;3(1):11-9.

12. Merla A, Mattei PA, Di Donato L, Romani GL. Thermal imaging of cutaneous temperature modifications in runners during graded exercise. Ann Biomed Eng. 2010;38(1):158-63.

13. Formenti D, Ludwig N, Trecroci A, Gargano M, Michielon G, Caumo A, et al. Dynamics of thermographic skin temperature response during squat exercise at two different speeds. JTherm Biol. 2016;59:58-63.

14. Korman P, Straburzyńska-Lupa A, Kusy K, Kantanista A, Zieliński J. Changes in body surface temperature during speed endurance work-out in highly-trained male sprinters. Infrared Phys Technol. 2016;78:209-13.

15. Fernandes AA, Amorim PRS, Brito CJ, Sillero-Quintana M, Marins JCB. Regional skin temperature response to moderate aerobic exercise measured by infrared thermography. Asian J Sports Med. 2016;7(1):1-8.

16. Tanda G. The use of infrared thermography to detect the skin temperature response to physical activity. J Phys Conf Ser. 2015;655.
17. Silva AG, Albuquerque MR, Brito CJ, Stroppa GM, Sillero-Quintana M, Marins JCB. Resposta térmica da pele ao exercício em remoergômetro de alta versus moderada intensidade em homens fisicamente ativos. Rev Port Ciências do Desporto. 2017;17:125-37.

18. Novotny J, Rybarova S, Zacha D, Novotny J, Bernacikova M, Ramadan W. Thermographic evaluation of muscle activity after front crawl swimming in young men. Acta Bioeng Biomech. 2017;19(4):109-16.

19. Araújo VA, Carvalho LS, Morais NA, Souza ES, Santos RMC, Souza PAC, et al. Análise termográfica dos membros inferiores de jovens ativos após uma sessão aguda de treinamento pliométrico. Rev Bras Prescrição e Fisiol do Exerc. 2018;12(72):56-62.

20. Quesada JIP, Martínez Guillamón N, De Anda RMCO, Psikuta A, Annaheim S, Rossi RM, et al. Effect of perspiration on skin temperature measurements by infrared thermography and contact thermometry during aerobic cycling. Infrared Phys Technol. 2015;72:68-76.

21. Ludwig N, Formenti D, Gargano M, Alberti G. Skin temperature evaluation by infrared thermography: Comparison of image analysis methods. Infrared Phys Technol. 2014;62:1-6.

22. Santa Cruz RAR, Araújo VA, Sousa P de AC de, Arruda JRL. Perfil termográfico de atletas de handebol após um jogo oficial. Rev Mov. 2018;11(1):12-9.

23. Johnson JM, Kellogg Jr DL. Thermoregulatory and Thermal Control in the Human Cutaneous Circulation. Front Biosci. 2010;2:825-53

24. Mortensen SP, Saltin B. Regulation of the Skeletal Muscle Blood Flow in Humans. Exp Physiol. 2014;99(12):1552-8

25. Côrte AC, Pedrinelli A, Marttos A, Souza IFG, Grava J, José Hernandez A. Infrared thermography study as a complementary method of screening and prevention of muscle injuries: Pilot study. BMJ Open Sport Exerc Med. 2019;5(1):1-5.

26. Selfe J, Whitaker J, Hardaker N. A narrative literature review identifying the minimum clinically important difference for skin temperature asymmetry at the knee. Thermol Int. 2008;18(2):41-4.

27. Stroppa G, da Silva A, Moreira D, Cerqueira M, Fernandes A, Bouzas J. Análise da temperatura da pele em joelhos de jogadoras de futebol profissional. Rev Bras Futeb. 2017;08(32):128-39.

28. Fernandes A de A, Pimenta EM, Moreira DG, Sillero-Quintana M, Bouzas Marins JC, Morandi RF, et al. Effect of a professional soccer match in skin temperature of the lower limbs: A case study. J Exerc Rehabil. 2017;13(3):330-4.

29. Varley MC, Aughey RJ. Acceleration Profiles in Elite Australian Soccer. Int J Sports Med. 2013;34(1):34-9.

30. Rodriguez-Sanz D, Losa-Iglesias ME, Bengoa-Vallejo RB, Palomo-Lopez P, Beltran-Alacreu H, CalvoLobo $C$, et al. Skin temperature in youth soccer players with functional equinus and non-equinus condition after running. J Eur Acad Dermatology Venereol. 2018:32(11):2020-4.

\section{ERRATA}

In the article entitled "ACUTE EFFECT OF SPEED TEST ON THE SKIN TEMPERATURE OF ELITE SOCCER PLAYERS " authored by Andressa Mella Pinheiro, Angélica Tamara Tuono, Nathália Arnosti Vieira, Tiago Marques de Rezende, Sérgio Henrique Borin, Charlini Simoni Hartz, Carlos Roberto Padovani, Fernando Carmelo Torres, João Paulo Borin, published in Rev Bras Med Esporte vol.27 no.1 São Paulo Jan./Mar. 2021 DOl: http://dx.doi.org/10.1590/1517$8692202127012020 \_0060$, pages 55-59 by request of the authors.

- On page 58, line 1

Where it reads: results that are close to those of this study

Read: results that are smaller to those of this study

- On pages 57 and 58

Tables 1, 2 e 3 respectively, should be substituted for the following tables:

Table 1. Mean temperature of the analyzed regions and standard deviation, according to the moment of evaluation.

\begin{tabular}{c|c|c|c|c}
\hline \multirow{2}{*}{ Limb } & \multirow{2}{*}{ ROIs } & \multicolumn{2}{|c|}{ Moments of evaluation } & \\
\cline { 3 - 5 } & & Pre-test & Post-test & $\begin{array}{c}\text { Temperature } \\
\text { difference }\left({ }^{\circ} \mathbf{C}\right)\end{array}$ \\
\hline \multirow{4}{*}{ Dominant } & Quadriceps & $28.7 \pm 0.6$ & $29.8 \pm 0.6^{*}$ & 1.1 \\
\cline { 2 - 5 } & Hamstrings & $28.6 \pm 0.4$ & $29.9 \pm 0.8^{*}$ & 1.3 \\
\cline { 2 - 5 } & Anterior tibialis & $28.7 \pm 0.5$ & $30.0 \pm 0.6^{*}$ & 1.3 \\
\cline { 2 - 5 } & Calf & $28.1 \pm 0.5$ & $29.2 \pm 0.8^{*}$ & 1.1 \\
\hline \multirow{3}{*}{ Non-dominant } & Quadriceps & $28.7 \pm 0.6$ & $29.9 \pm 0.7^{*}$ & 1.2 \\
\cline { 2 - 5 } & Hamstrings & $28.8 \pm 0.4$ & $30.0 \pm 0.8^{*}$ & 1.2 \\
\cline { 2 - 5 } & Anterior tibialis & $28.8 \pm 0.6$ & $30.0 \pm 0.6^{*}$ & 1.2 \\
\cline { 2 - 5 } & Calf & $28.1 \pm 0.5$ & $29.5 \pm 0.7^{*}$ & 1.4 \\
\hline
\end{tabular}

${ }^{*} p<0.05$.

Table 2. Mean temperature of the analyzed regions and standard deviation, according to dominance.

\begin{tabular}{|c|c|c|c|c|c|c|c|c|}
\hline \multirow{3}{*}{ Moments } & \multicolumn{8}{|c|}{ Analyzed regions } \\
\hline & \multicolumn{2}{|c|}{ Quadriceps } & \multicolumn{2}{|c|}{ Hamstrings } & \multicolumn{2}{|c|}{ Anterior tibialis } & \multicolumn{2}{|c|}{ Calf } \\
\hline & Dominant & Non-dominant & Dominant & Non-dominant & Dominant & Non-dominant & Dominant & Non-dominant \\
\hline Pre $\left({ }^{\circ} \mathrm{C}\right)$ & $28.7 \pm 0.6$ & $28.7 \pm 0.6$ & $28.6 \pm 0.4$ & $28.8 \pm 0.4$ & $28.7 \pm 0.5$ & $28.8 \pm 0.6$ & $28.1 \pm 0.5$ & $28.1 \pm 0.5$ \\
\hline Post $\left({ }^{\circ} \mathrm{C}\right)$ & $29.8 \pm 0.6$ & $29.9 \pm 0.7$ & $29.9 \pm 0.8$ & $30.0 \pm 0.8$ & $30.0 \pm 0.6$ & $30.0 \pm 0.6$ & $29.2 \pm 0.8$ & $29.5 \pm 0.7$ \\
\hline
\end{tabular}

Table 3. Mean temperature of the anterior and posterior regions of the lower limbs and standard deviation, according to the moment of evaluation.

\begin{tabular}{c|c|c|c|c}
\hline & \multicolumn{3}{c}{ ROIs } \\
\hline & \multicolumn{2}{|c|}{ Dominant side } & \multicolumn{2}{c}{ Non-dominant side } \\
\hline Moments & Quadriceps & Hamstrings & Quadriceps & Hamstrings \\
\hline Pre & $28.7 \pm 0.6$ & $28.6 \pm 0.4$ & $28.7 \pm 0.6$ & $28.8 \pm 0.4$ \\
\hline Post & $29.8 \pm 0.6$ & $29.9 \pm 0.8$ & $29.9 \pm 0.7$ & $30.0 \pm 0.8$ \\
\hline & Anterior tibialis & Calf & Anterior tibialis & Calf \\
\hline Pre & $28.7 \pm 0.5^{*}$ & $28.1 \pm 0.5$ & $28.8 \pm 0.6^{*}$ & $28.1 \pm 0.5$ \\
\hline Post & $30.0 \pm 0.6^{*}$ & $29.2 \pm 0.8$ & $30.0 \pm 0.6^{*}$ & $29.5 \pm 0.7$ \\
\hline
\end{tabular}

${ }^{*} p<0.05$. 